\title{
HASIL PENELITIAN TERBARU: BENTUK DAN KARAKTER SITUS SEMARUM
}

\section{The Latest Results: Form \& Character of Semarum Site}

\author{
Hery Priswanto \\ Balai Arkeologi Yogyakarta \\ priswanto.balaryk@gmail.com
}

\begin{abstract}
Ancient brick structures were found in 1990 in Semarum site in the regency of Trenggalek. Intensive research have been carried out since 2012 to 2014. Systematic excavation was conducted to disclose the form and character of the site. The Data collection research through excavation activities with qualitative research methods. The result showed that Semarum site is an ancient water reservoir made of brick measuring $24 \mathrm{~m} \times 24 \mathrm{~m}$. Absolute chronology determination is still in the process, while the relative date is estimated between the XI - XIII centuries AD or between Kadiri to Maj apahit period.
\end{abstract}

Keywords: Semarum Site, Ancient Brick Structure, Ancient Reservoir

\begin{abstract}
ABSTRAK
Sebuah struktur bata kuno pada tahun 1990 telah ditemukan di situs Semarum yang berada di Kabupaten Trenggalek.Penelitian intensif struktur bata kuno di Situs Semarum dilakukan sejak 2012 hingga 2014.Penggalian sistematis dilakukan untuk mengungkapkan bentuk dan karakter situs. Pengumpulan data penelitian melalui kegiatan ekskavasi dengan metode penelitian kualitatif. Hasil penelitian menunjukkan bahwa situs Semarum merupakan penampungan air kuno yang terbuat dari batu bata berukuran 24 meter x 24 meter. Penentuan kronologi mutlak masih dalam proses, sedangkan tanggal relatif diperkirakan antara XI yang - XIII abad AD atau antara Kadiri periode Majapahit.
\end{abstract}

Kata kunci: Situs Semarum, struktur bata kuna, waduk kuna

\footnotetext{
Tanggal masuk : :10 Mei 2015
}

Tanggal diterima :16 Juni 2015

Hasil Penelitian Terbaru: Bentuk dan Karakter Situs Semarum (Hery Priswanto) 


\section{PENDAHULUAN}

Keberadaan Situs Semarum berawal dari penemuan tahun 1990an (Antara News) oleh warga bernama Kosim(45, petani). Pada waktu itu lokasi penemuan akan digali untuk membuat lubang pembuangan sampah, tetapi ketika digali ditemukan struktur pagar kuna. Penemuan tersebut tidak segera dilaporkan, tetapi oleh penemu kemudian ditimbun kembali. Lama tidak terdengar kabarnya, pada sekitar bulan November 2011, tidak jauh dari lokasi temuan pertama (10 meter sebelah timurnya) di lahan milik warga bernama Kaseni (60, petani) juga ditemukan struktur serupa dengan temuan pada tahun 1990-an. Penemuan ini pada awalnya tidak disengaja, karena lokasi tersebut akan diambil tanahnya untuk dibuat adonan bata merah. Pada waktu digali ternyata terdapat struktur yang masih utuh dan insitu. Temuan itu juga tidak dilaporkan ke instansi terkait,justru tetapi ditutup kembali karena ada perasaan takut pada diri penemu (Utomo, 2012: 7).

Masih di bulan November 2011 secara kebetulan juru pelihara Candi Brongkah, Trenggalek bernama So'im berkunjung ke rumah penemu yang juga masih kerabatnya, sehingga diceritakan perihal temuan tersebut. Hal itu kemudian ditindaklanjuti oleh juru pelihara Candi Brongkah dengan melapor ke instansi Dinas Pemuda dan Olahraga Kabupaten Trenggalek hingga informasi tersebut muncul di berbagai media massa. Dinas Pemuda dan Olahraga Kabupaten Trenggalek selanjutnya melakukan peninjauan ke lokasi pada tanggal 2, 4, dan 5 April 2012.

Berdasarkan informasi tersebut Balai Pelestarian Peninggalan Purbakala Jawa Timur segera melakukan peninjauan ke lokasi temuan pada tanggal 9 April 2012 berkaitan dengan upaya-upaya pengamanan, pendataan, dan kajian arkeologis untuk memastikan kekunaan temuan tersebut. Hasil peninjauan diperoleh informasi yaitu:

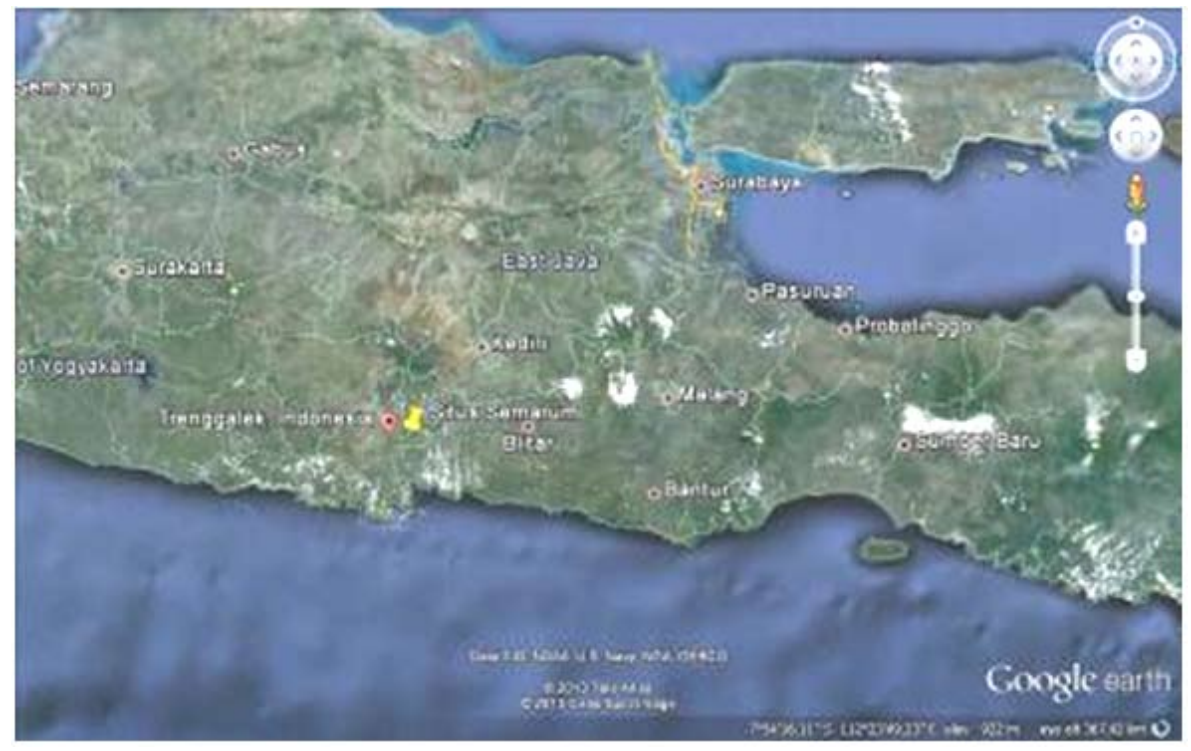

Gambar 1. Lokasi Situs Semarum (sumber:googleearth) 
- $\quad$ Struktur yang diduga pagar kuna dengan material dari bata merah. Struktur tersebut menggunakan teknik pemasangan kosod sehingga tidak menggunakan spesi sebagai perekat. Pada bagian bawah struktur tidak ditemukan adanya pengerasan (pondasi), atau langsung dipasang di atas tanah.

- $\quad$ Tinggi struktur 1,10 meter; tebal bagian atas diperkirakan 0,67 meter (tebal yang tampak 0,47 meter); dan panjangnya 24 meter. Salah satu bata sebagai sampel memiliki panjang 47 $\mathrm{cm}$; tebal $10 \mathrm{~cm}$; dan lebar $25 \mathrm{~cm}$.

- Posisi struktur bagian atas tidak terlalu dalam dari permukaan tanah sekarang. Orientasi struktur memanjang arah barat-timur, dan pada masing-masing ujungnya berbelok siku $\left(90^{\circ}\right)$ ke arah selatan. Struktur sisi timur yang mengarah selatan hanya terlacak sepanjang 6,80 meter, sedangkan struktur sisi barat yang mengarah ke selatan masih belum tampak (masih di dalam tanah) (Utomo, 2012: 8- 9).

Berdasarkan laporan awal dari BPCB Jawa Timur, Balai Arkeologi Yogyakarta pada akhir tahun 2012 hingga tahun 2014 melakukan penelitian di Situs Semarum secara intensif dan berkelanjutan. Metode pencarian data yang digunakan berupa ekskavasi dan penelusuran data sekunder berupa referensi pendukung melalui data pustaka maupun data digital.

Penelitian Situs Semarum tahun 2012 dibuka tiga kotak ekskavasi yaitu kotak B1U1, B7U4, B11U6, dan B12 U6. Struktur bata yang semula diperkirakan sebuah struktur pagar kuna, berdasarkan hasil penelitian diduga merupakan sebuah bangunan petirtaan kuna (Tim penelitian, 2012). Penelitian Situs Semarum Tahun 2013 menemukan struktur bata di kotak S4B3 dan S9B9 yang mempunyai ciri sama dengan struktur bata yang ditemukan pada tahun 2012. Kondisi temuan pada kotak S9B9 sudah tidak utuh lagi, diduga di lokasi ini pernah dilakukan pengolahan tanah sehingga merusak struktur bata.Pada tahap ini digunakan alat bantu berupa Auger (bor besi) untuk pendeteksian temuan di bawah tanah dengan melakukan pemboran tanah sebelum melakukan pembukaan kotak ekskavasi. Dari penelitian ini diperoleh data mengenai denah dan luas Situs Semarum. Denah struktur bata Situs Semarum diperkirakan berbentuk persegi dengan ukuran 24 x 24 meter seluas 576 meter2. (Tim Penelitian, 2013).

Penelitian Situs Semarum tahun 2014 bertujuan untuk memperoleh data mengenai fungsi bangunan dan kronologi situs. Berdasarkan hasil penelitiandiperolehinformasimengenai fungsi situs sebagai bangunan hidrolik, yaitu reservoir (penampungan air). Hal ini didukung dengan kondisi lingkungan di sekitar situs yaitu adanya Sungai Ngasinan dan kondisi lahan dengan fluktuasi musim yang berbeda (kering di musim kemarau dan banjir di saat musim penghujan (Tim penelitian, 2014).

Berdasarkan hasil penelitian selama tahun 2012 hingga 2014 di Situs Semarum, maka secara umum tujuan penulisan artikel ini memberikan informasi awal mengenai bentuk dan karakter Situs Semarum.Keberadaan Situs Semarum inimempunyai nilai penting bagi Kabupaten Trenggalek selain Candi Brongkah, namun dari segi pelestarian cagar budaya sangatlah jauh dari harapan. Hal ini dikarenakan lokasi situs yang berada di tengah perkampungan padat penduduk, 
sehingga rawan mengalami kerusakan dan kehancuran.

\section{HASIL PENELITIAN SITUS SEMARUM}

\section{Lokasi dan Lingkungan Fisik Situs Semarum}

Kegiatan survei lingkungan difokuskan pada lingkungan fisik dan di wilayah Desa Semarum.Pengamatan terhadap lingkungan fisik dilakukan terhadap fitur-fitur lingkungan fisik dominan adalah aliran Sungai Ngasinan yang berada di sebelah selatan Desa Semarum serta beberapa aliran sungai yang berasal dari sebelah utara desa seperti Kali Jurangbanteng dan Sungai Sedongo.Sungai Ngasinan mengalir dari Trenggalek ke Tulungagung melalui wilayah Kec Durenan bagian tengah. DAS Ngasinan merupakan salah satu bagianhuluSungai Brantasyang terletak di wilayah kabupatenTrenggalek dan Tulungagung, Propinsi Jawa Timur, yangmengalir ke Sungai Ngasinan kemudian ke Sungai Ngrowodan

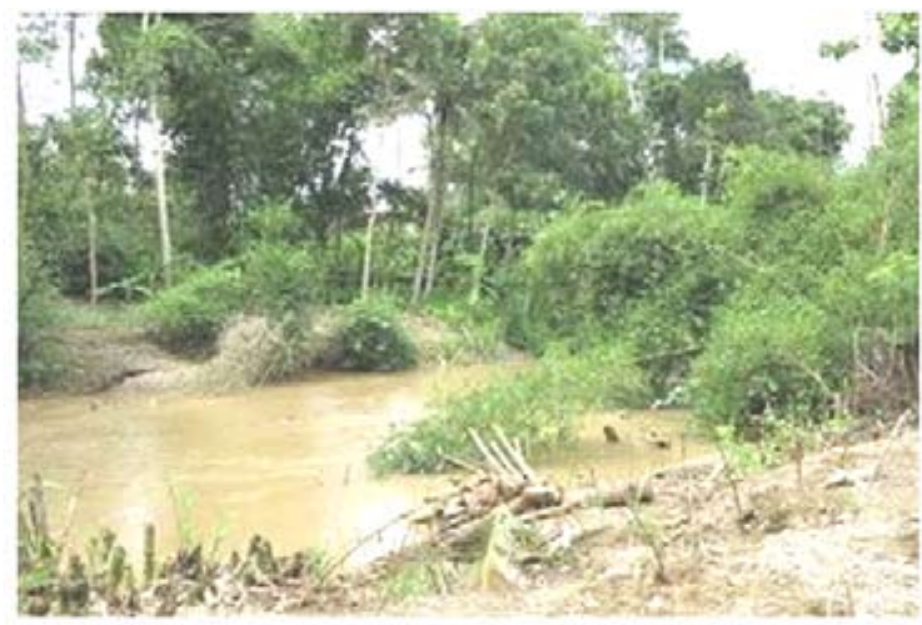

Gambar 2. Sungai Ngasinan yang berada di sebelah Selatan Desa Semarum (Sumber: Dok. Balai Arkeologi Yogyakarta, 2012)

yang dominan yang ditemui di lokasi sekitar situs.Secara administrasi Desa Semarum merupakan wilayah Kecamatan Durenan, Kabupaten Trenggalek, Propinsi Jawa Timur. Desa Semarum berbatasan dengan Desa Pakis dan Desa Pandean di sebelah timur; Sungai Ngasinan di sebelah selatan; desa Kendalrejo di sebelah barat; dan Gunung Bali di sebelah utara.

Lingkungan fisik Desa Semarum sebagian besar berupa dataran alluvial yang dimanfatkan untuk lahan pertanian dan permukiman. Fitur alam yang terakhir ke Sungai Brantas. DAS Sungai Ngasinansebagai salah satu hulu sungai Brantas termasuk dalamDAS yang memiliki daerah tangkapan hujan paling luasdaripada DAS yang lain.

Di wilayah Kabupaten Trenggalek bagian utara membentang Pegunungan Rajegwesi,antara lain Pringulung, Condrogeni,Gunung Cilik Ngesong, Tumpak Cenil, Watu Blandong, Gunung Kekep dan salah satunya Gunung Bale. Gunung Bale ini merupakan salah satu fitur alam yang menonjol di wilayah Desa Semarum yang berada di sisi utara Desa 
Semarum.

Keletakan Situs Semarum secara astronomis berada pada 080 06' 42.96" Lintang Selatan dan 1110 47' 34.93" Bujur Timur pada ketinggian 101 meter dpal. Situs Semarum merupakan sebidang tanah tegalan milik tiga keluarga yaitu keluarga Bapak Kaseni, Bapak Kosim, dan Bapak Taji yang berada di RT 05 RW 02 Desa Semarum, Kecamatan Durenan, Kabupaten Trenggalek.Situs Semarum merupakan sebuah situs arkeologi dengan temuan berupa singkapan struktur bata yang berorientasi TimurBarat (Utomo, 2012).

Kondisi lingkungan Situs Semarum berupa tanah tegalan yang subur dan ditanami ketela pohon(Manihot esculenta), kelapa (Cocos nucifera), coklat (Theobroma cocoa), pisang (Musacaea), dan bambu (Bambuseae). Menurut informasi dari narasumber, Bapak Musirin (76 tahun), sekitar tahun 1950-an di sebelah utara singkapan bata pernah dijumpai sebuah aliran sungai dengan debit air tidak begitu deras, namun keberadaan sungai tersebut sudah tidak dapat dijumpai lagi. (Tim Penelitian, 2013: 34)

\section{Bentuk Situs Semarum}

Situs Semarum merupakan sebuah bangunan tinggalan arkeologi berbahan bata. Penggunaan bata sebagai bahan penyusun struktur bangunan juga dijumpai Candi Brongkah di Desa Kedunglurah, runtuhan bata-bata kuna di Desa Kendalrejo, dan informasi adanya bata-bata kuna di Desa Kamulan. Penggunaan bata sebagai bahan penyusun struktur bangunan juga didukung dengan melimpahnya sumber bahan di sekitar aliran Sungai Ngasinan.Hingga saat ini aktivitas pembuatan bahan bangunan dengan menggunakan tanah liat yang dibakar seperti bata dan genteng masih dapat kita saksikan di wilayah Kecamatan Durenan khususnya di Desa Kamulan sebagai sentra pembuatan bata dan genteng.

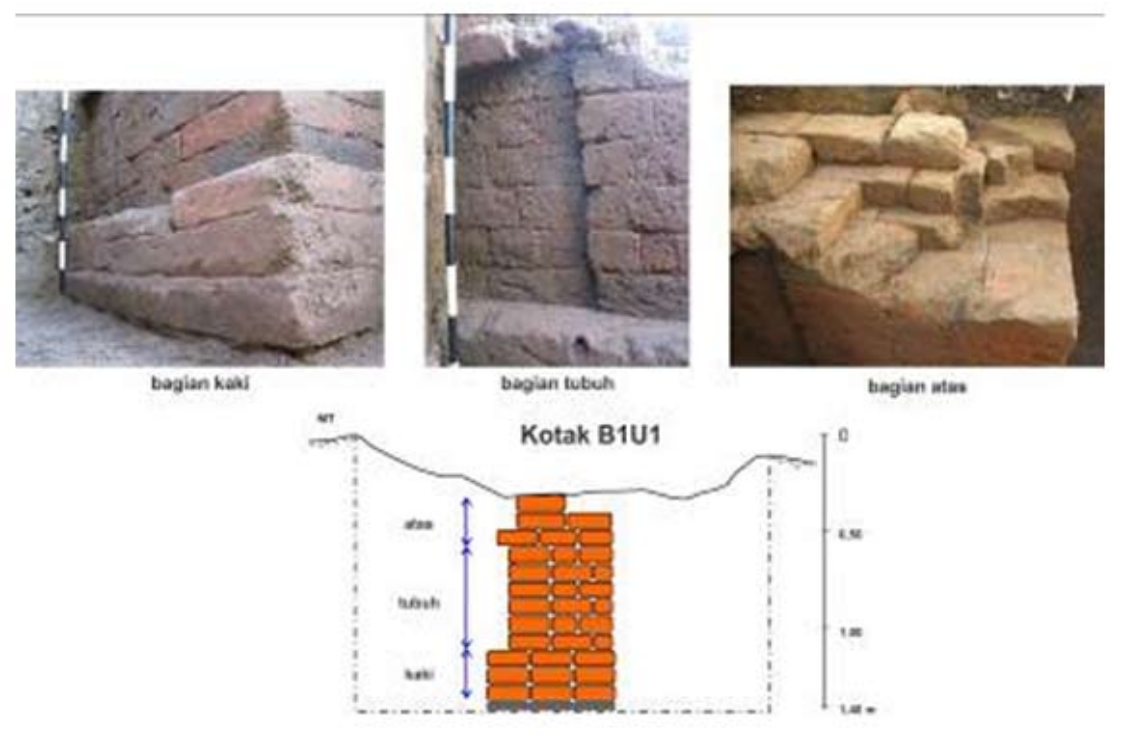

Gambar 3. Konstruksi struktur bata Situs Semarum

(Sumber: Gambar Kotak B1U1 Situs Semarum-Balai Arkeologi Yogyakarta, 2012)

Hasil Penelitian Terbaru: Bentuk dan Karakter Situs Semarum 
Struktur bata Situs Semarum menggunakan teknik pemasangan kosodsehingga tidak menggunakan spesi sebagai perekat.Pada bagian bawah struktur tidak ditemukan adanya pengerasan (pondasi), yaitu langsung dipasang di atas tanah. Struktur memiliki tinggi 1,10 meter; tebal bagian atas sekitar 0,67 meter (tebal yang tampak 0,47 meter); dan x 24 meter dengan perkiraan luas 576 $\mathrm{m} 2$.

Berdasarkan rekonstruksi grafis dugaan karakter Situs Semarum sebagai situs segaran atau reservoir didasarkan pada bentuknya yang relatif besar dan luas.Hal ini mengingatkan pada bentuk pada salah satu tinggalan arkeologi sejenis yang dijumpai di Trowulan - Mojokerto yaitu di Situs

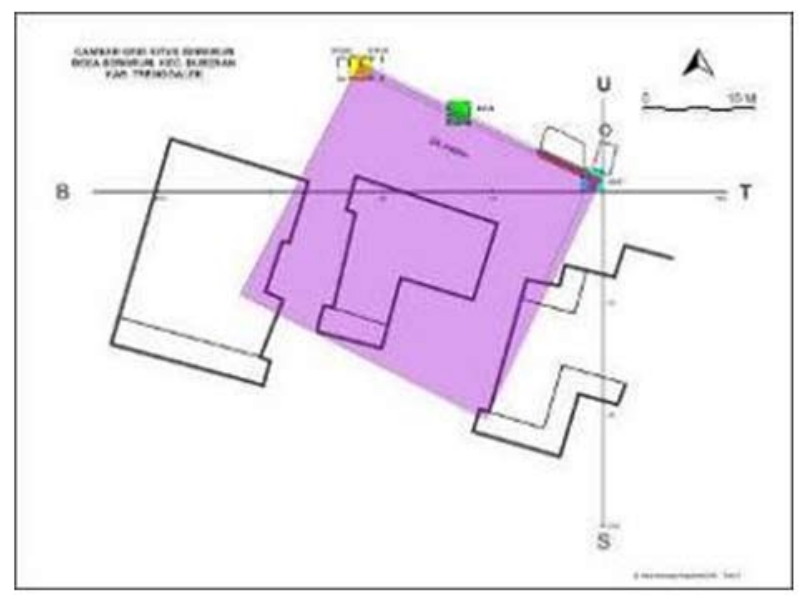

Gambar 4. Luas Situs Semarum berukuran 24 x 24 meter

panjang 24 meter. Salah satu sampel bata memiliki panjang $47 \mathrm{~cm}$; tebal 10 $\mathrm{cm}$; dan lebar $25 \mathrm{~cm}$.(Tim Penelitian, 2012).

\section{Berdasarkan analisis} morfologi atau bentuk, denah struktur mengacu pada bentangan struktur bata sepanjang 24 meter berbentuk bujursangkar dengan ukuran 24 meter
Kolam Segaran.Kolam Segaran yang mempunyai luas 6 hektar ini mempunyai daya tampung $223.123 \mathrm{~m} 3$. Pada saat ditemukan pertama kali pada tahun 1926 dan dipugar pada tahun 1984.Di sisi barat kolam segaran dijumpai pintu masuk dan tangga turun ke kolam. Di beberapa sisi terdapat saluran yang mengalir ke dalam kolam (inlet) dan adapula yang mengalir keluar ke saluran

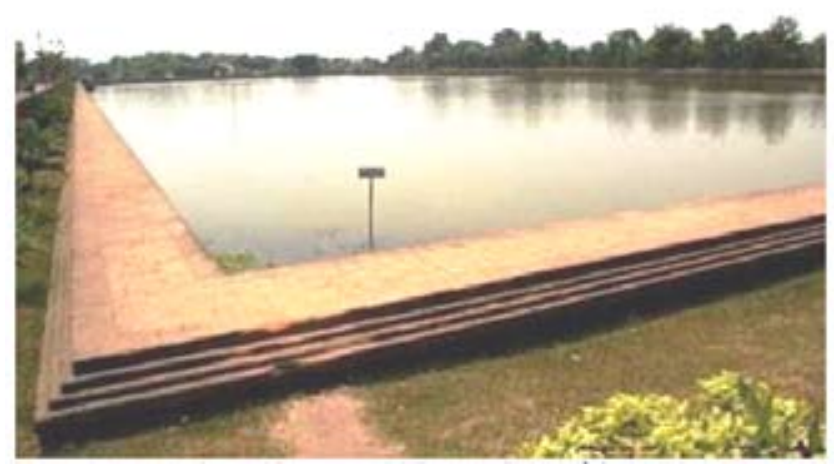

Gambar 5. Situs Kolam Segaran di Trowulan, Mojokerto (Sumber: Dok. BPCB Jawa Timur) 
pembuangan (outlet). (Susantini, 2007: 11-12).

Asumsinya bahwa pengamatan bentuk dan bahan penyusun struktur bata di Situs Semarum hampir mirip dengan Situs Kolam Segaran Trowulan, namun apabila dibandingkan dengan keluasan situs dijumpai adanya perbedaan (Tim Penelitian, 2014). Kolam Segaran Trowulan sebagai salah satu kolam buatan diduga berfungsi sebagai pencegah banjir di musim penghujan, dan sebagai persedian air di musim kemarau (Wibowo, A.S., 1977: 47). Hal ini juga didukung dengan data arkeologi lainnya di Trowulan yaitu berupa kanal-kanal kuna (Riyanto, 2010: 29).

\section{Karakter Situs Semarum}

Berdasarkan hasil peninjauan (Utomo, 2012) Balai Pelestarian Cagar Budaya Jawa Timur, temuan di Desa Semarum, Kecamatan Durenan, Kabupaten Trenggalek berupa struktur bata tersebut diperkirakan

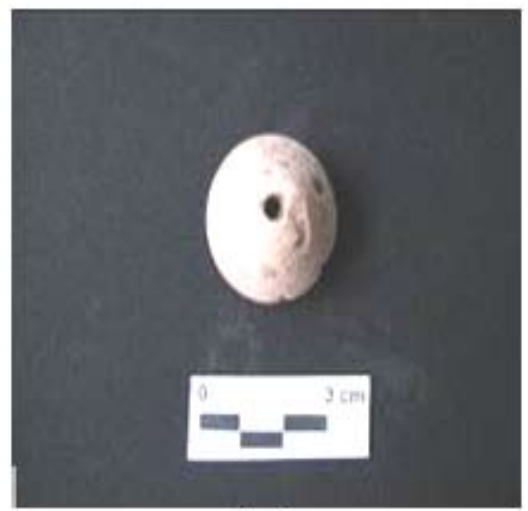

(a) yang berkaitan dengan kehidupan keseharian dan tidak berkaitan dengan kegiatan keagamaan (sakral). Temuan struktur bata pada awalnya diduga sebagai bangunan pagar, namun berdasarkan hasil penelitian tahun 2014 diduga fungsi Situs Semarum merupakan sebuah bangunan yang berkaitan dengan bangunan air kuna (hydraulic structure) yaitu reservoir yang secara umum berfungsi sebagai penampung air. Berdasarkan informasi dari Kepala Desa Semarum, Bapak Agus Priyanto, diketahui bahwa di Desa Semarum ketika musim kemarau akan kekurangan air namun ketika musim penghujan terjadi banjir (Tim Penelitian, 2014).

\section{Keberadaan air pada lampau} di Situs Semarum ini sangatlah penting bagi masyarakat yang berada di sekitarnya.Secara konseptual air merupakan fons vitae atau sumber hidup, oleh karena itu di dalam masyarakat Jawa sejak dahulu dikenal bermacam-macam istilah

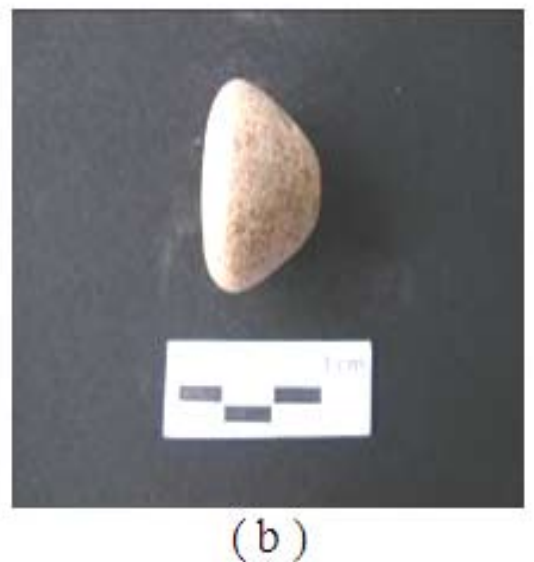

Gambar 6. Detail bandul jala berbahan terakota/gerabah (a) tampak atas (b) tampak samping (Sumber: Dok. Balai Arkeologi Yogyakarta, 2012)

adalah sebuah struktur pagar. Namun setelah melalui penelitian hingga tiga tahap, karakter Situs Semarum berdasarkan bentuk struktur bata yang telah ditemukan lebih mengacu kepada sebuah bangunan profan atau yang menyangkut air kehidupan yaitu salah satunya kata amrta, tirta nirmala, dan toya marta(Atmodjo, 1983: 9-11). Dengan ditemukannya Situs Semarum yang diduga merupakan bangunan air kuna(hydraulic structure) yaitu reservoir 
ini menambah data cagar budaya yang berkaitan dengan pengairan. Data arkeologi yang berkaitan dengan pengairan yaitu candi petirtaan, kanal, dan bendungan/dam.

Indikasi dugaan Situs Semarum dugaan sebagai bangunan air yaitu dijumpainya sebuah outlet pada bagian sudut timur laut struktur bata, bandul jala yang terbuat dari tanah liat bakar serta lapisan pasir dan kerakal di bagian dalam struktur bata. Informasi adanya lapisan pasir dan kerakal ini juga dijumpai di Situs Kolam Segaran Trowulan yang pada bagian dasar kolam juga dijumpai data berupa pasir dan batu kali (Siagian, 2002: 197).

Pembahasan kronologi atau
M/ 1116 Ç oleh Raja Sri Sarweswara Triwikramataranindita Srengga Lancana Dikwijayatunggadewa atau lebih dikenal dengan sebutan Kertajaya (Raja Kediri) bertuliskan hari, tanggal, bulan, dan tahun pembuatannya yang kemudian ditetapkan sebagai Hari Jadi Kabupaten Trenggalek (Utomo, 2012:4-5)

Berdasarkan hasil penelitian arkeologi Situs Semarum diperoleh informasi mengenai kronologi/periodesasi secara relatif, yaitu sekitar abad XI - XIII M. Penentuan periodesasi secara relatif

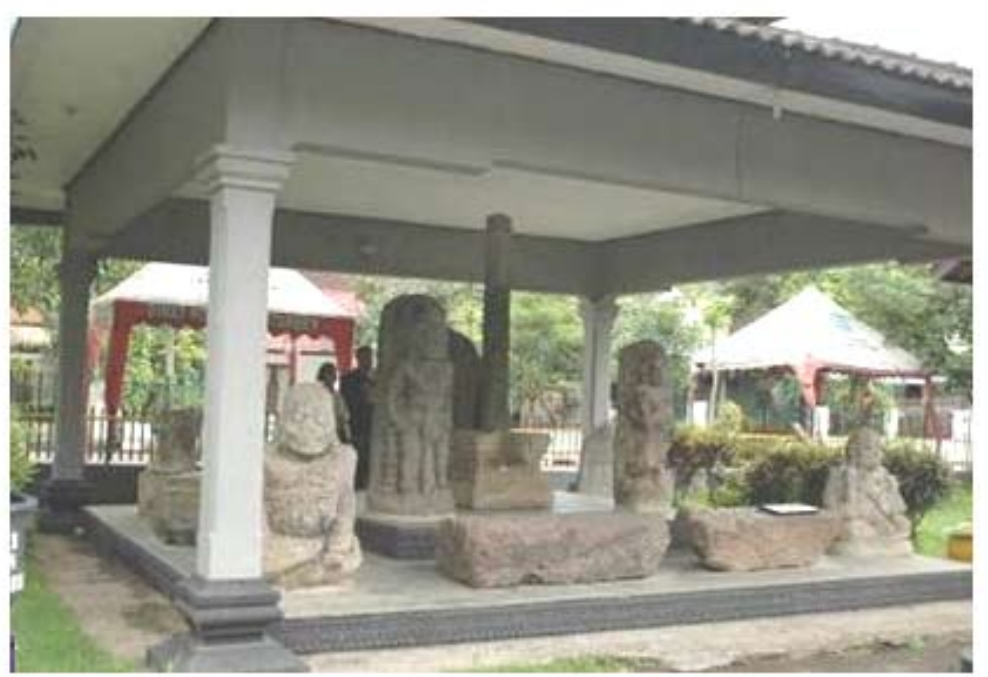

Gambar 7. Morfologi Nekara Dong Son

periodesasi Situs Semarum tidak terlepas darisejarah Kabupaten Trenggalek. Kabupaten Trenggalek dengan kondisi alam yang mendukung, berupa gunung-gunung kecil yang tidak aktif dan lebih mirip disebut perbukitandan sungai yang lebar salah satunya Sungai Ngasinan Dengan kondisi bentang lahan yang demikian, tampaknya Trenggalek telah dijadikan hunian yang cukup lama. Salah satunya data sejarah berupa Penemuan Prasasti Kamulan 1194 ini berdasarkan data arkeologi yang ditemukan di Situs Semarum berupa data artefaktual dan data arsitektural yang kemudian dikomparasikan dengan tinggalan-tinggalan arkeologi yang berada di sekitar Situs Semarum. Data artefaktual berupa gerabah halus yang dijumpai di situs ini merupakan jenis gerabah yang lazim ditemukan pada situs-situs masa periode Majapahit di Jawa Timur. Hal ini juga mengacu pada dominasi kuantitas temuan gerabah halus di Situs Semarum.Data artefaktual 

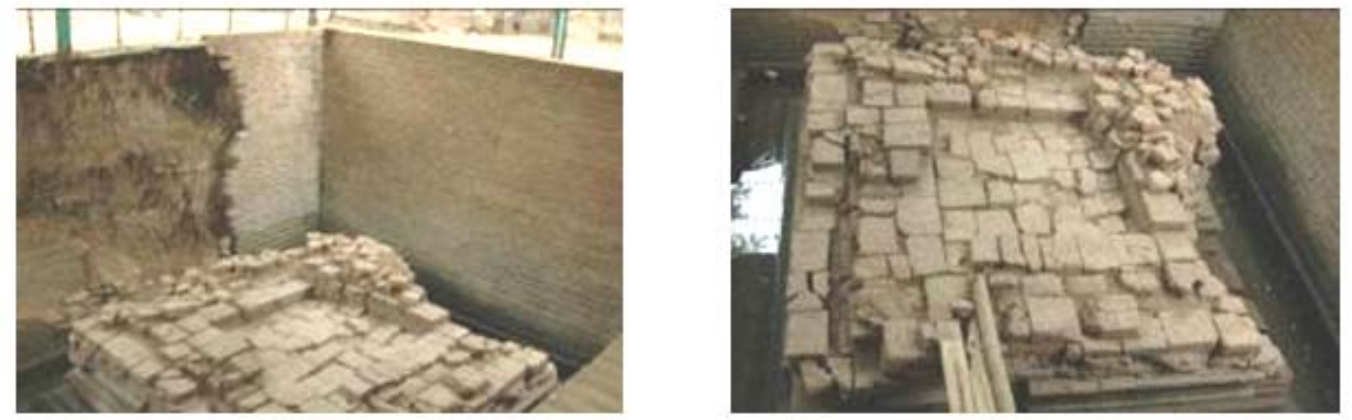

Gambar 8. Kondisi Candi Brongkah pada saat dilakukan survei (a), Profil bagian atas Candi Brongkah dilihat dari sisi timur (b). (Sumber: Dok. Balai Arkeologi Yogyakarta, 2012)

berupa keramik asing dari Cina yang berseladon diperkirakan berasal dari dinasti Song $(960-1279$ M).Secara umum data artefakgerabah dan keramik asing ini secara umum mengacu pada masa Majapahit yaitu sekitar abad XIII masehi. Untuk mengetahui periodesasi struktur bata yang ditemukan di Situs Semarum dilakukan kajian komparasi atau perbandingan dengan tinggalan arkeologi yang berada disekitarnya. Tinggalan arkeologi yang terdekat dengan situs Semarum adalah Candi Brongkah.Candi Brongkah adalah bangunan candi berbahan bata yang lokasinya berada di sebelah barat Situs Semarum berjarak 1.693, 63 meter. Candi Brongkah merupakan bangunan candi satu-satunya yang dimiliki Kabupaten Trenggalek merupakan bangunan candi Hindu dari periode Masa Majapahit (Siagian, 2002: 206).

\section{Nilai Penting Situs Semarum}

Mengacu kepada UndangUndang Cagar Budaya nomor 11 tahun 2010 pasal 1 ayat 1 bahwa Situs Semarum yang berada di Desa Semarum, Kecamatan Durenan, Kabupaten Trenggalek merupakan sebuah situs yang mempunyai nilai penting. Nilai penting yang dimaksud adalah Situs Semarum mempunyai nilai penting nilai penting bagi sejarah, ilmu pengetahuan, pendidikan, agama, dan/atau kebudayaan melalui proses penetapan. Pada UU CB No. 11 Tahun 2010 disebutkan bahwa: "Cagar Budaya adalah warisan budaya bersifat kebendaan berupa Benda Cagar Budaya, Bangunan Cagar Budaya, Struktur Cagar Budaya, Situs Cagar Budaya, dan Kawasan Cagar Budaya di darat dan/atau di air yang perlu dilestarikan keberadaannya karena memiliki nilai penting bagi sejarah, ilmu pengetahuan, pendidikan, agama, dan/atau kebudayaan melalui proses penetapan"

Temuan dan keberadaan Situs Semarum mempunyai nilai penting bagi sejarah dan ilmu pengetahuan khususnya wilayah Kabupaten Trenggalek maupun historiografi Indonesia secara umum adalah menambah data sejarah dan tinggalan cagar budaya.Data arkeologi yang ditemukan di Situs Semarum ini menambah aset tinggalan arkeologi di Kabupaten Trenggalek.Berdasarkan data BPCB Trowulan bahwa sebaran cagar budaya bergerak dan tak bergerak di Kabupaten Trenggalek sebanyak 17 cagar budaya.

Materi pendidikan yang mengacu pada muatan lokal yang salah satunya berdasarkan potensi budaya dan historis seperti tinggalan cagar budaya di Situs Semarum diharapkan memberikan kontribusi yang signifikan dalam penting penguatan pendidikan 
karakter, khususnya mengenai karakter dan jati diri sebagai warga Kabupaten Trenggalek. SitusSemarummempunyai nilai penting bagi kebudayaan daerah maupun kebudayaan nasional. Keberadaan Situs Semarum di Desa Semarum Kecamatan Durenan ini merupakan sebuah indikasi adanya sebuah peradaban yang sudah maju mengenai pengetahuan akan seni bangun arsitektur.

Berkenaan dengan nilai penting Situs Semarum berdasarkan hasil penelitian yang dilaksanakan Balai Arkeologi Yogyakarta ini dipandang perlu melakukan kegiatan pelestarian. Mengacu kepada Undang-Undang Cagar Budaya No 11 Tahun 2010 pasal 1 ayat 22 yaitu:" Pelestarian adalah upaya dinamis untuk mempertahankan keberadaan Cagar Budaya dan nilainya dengan cara melindungi, mengembangkan, dan memanfaatkannya. "

Oleh karena itu kegiatan pelestarian Situs Semarum ini segera dilakukan karena untuk mencegah terjadi kerusakan dan kehancuran Situs Semarum yang diakibatkan oleh manusia maupun alam.Salah satu upaya yang dilakukan membangun pagar pengaman, pengatapan, dan mengangkat juru pelihara yang dikoordinasikan antara BPCB Trowulan dan pemerintah setempat.

Sebuah usulan konstruktif mengenai optimalisasi potensi Situs Semarum bagi kabupaten Trenggalek mengenai pihak-pihak yang berwenang berkaitan dengan pelestarian dan pemanfaatan Situs Semarum.Berkenaan dengan lokasi Situs Semarum yang berada di tengah permukiman padat penduduk dan status tanah masih milik perseorangan, potensi kerusakan dan musnahnya Situs sangat besar.Dalam hal ini pihak pemerintah kabupaten Trenggalek c.q.Dinas Pariwisata, Pemuda, dan Olah
Raga Kabupaten Trenggalek - Dinas Pendidikan Kabupaten Trenggalek bersama dengan BPCB Trowulan yang bersentuhan langsung dengan Situs Semarum untuk memperoleh solusi tersebut di atas.

Mengacu pendapat Iseminger dalam Priswanto dan Alifah (2013:159) berkenaan dengan kepentingan publik dengan cagar budaya dapat di klasifikasikan dalam delapan tingkatan yaitu:

- Para arkeolog dan antropolog

- Pemerhati benda cagar budaya

- Kolektor

- Akademisi perguruan tinggi

- Wisatawan

- Masyarakat umum

- Para pendidik (guru)

- Mahasiswa

Apabila dikaitkan dengan pendapat Iseminger tersebut, hingga saat ini masyarakat lokal atau publik di kabupaten Trenggalek belum merasakan manfaat keberadaan Situs Semarum, hanya terbatas pada para peneliti dan pemerhati benda cagar budaya. Oleh sebab itu optimalisasi keberadaan Situs Semarum ini bagi masyarakat secara luas dapat dilakukan melalui kegiatan sosialisasi dan publikasi hasil-hasil penelitian secara kontinyu melalui pameran cagar budaya dan hasil penelitian arkeologi di Kabupaten Trenggalek.

\section{PENUTUP}

Berdasarkan uraian hasil penelitian yang telah dilakukan di Situs Semarum selama tiga tahapan dapat disimpulkan dalam butir-butir berikut ini:

- Bentuk dan karakter Situs Semarum dipengaruhi oleh kondisi lingkungan, yaitu berada di dataran rendah dengan sisi utara dibatasi oleh Gunung Bale dan di sisi dibatasi oleh 
Sungai Ngasinan.

- Secara teknis penyambungan bata menggunakan teknik kosod sehingga tidak menggunakan spesi sebagai perekat. Pada bagian bawah struktur tidak ditemukan adanya pengerasan (pondasi) atau langsung dipasang di atas tanah. Struktur bata ini memiliki tinggi 1,10 meter terdiri dari 12 lapis bata; lebar struktur diperkirakan 0,60 meter.Salah satu bata sebagai sampel memiliki panjang $47 \mathrm{~cm}$; tebal $10 \mathrm{~cm}$; dan lebar $25 \mathrm{~cm}$.

- Bentuk dan karakter situs Semarum yang berkaitan dengan data arkeologi berupa struktur bata diduga sebuah bangunan profan. Bangunan profan di situs Semarum berupa bangunan air (hydrolic building) yaitu untuk penampungan air (reservoir) dengan seluas 24 meter x 24 meter. Selain data arsitektural berupa struktur bata dan data artefaktual berupa sebuah bandul terakota, data lingkungan fisik situs Semarum berupa stratigrafi memperkuat dugaan tersebut.

- Berkenaan dengan nilai penting Situs Semarum, kegiatan pelestarian Situs dipandang perlu untuk dilakukan berupa pemagaran dan pengatapan serta pengangkatan juru pelihara situs dengan melakukan koordinasi bersama BPCB Jawa Timur dan Pemerintah Kabupaten Trenggalek.

- Papan informasi Situs Semarum yang memberikan informasi mengenai lokasi, sejarah penemuan serta penelitian Situs Semarum sehingga transformasi informasi kepada berbagai kalangan dapat tersampaikan 


\section{DAFTAR PUSTAKA}

cagar Budaya

Undang-Undang Republik Indonesia No. 11 Tahun 2010 Tentang

Atmodjo, M.M. Sukarto K, 1983. Arti Air Penghidupan Dalam Masyarakat Jawa", Yogyakarta: Proyek Javanologi

Priswanto, Hery \& Alifah, 2013. "Optimalisasi Potensi dan Tata Kelola Kawasan

Cagar Budaya Pleret” dalam Arkeologi dan Publik. Yogyakarta: Kepel Press.

Riyanto, Sugeng. 2010. "Tinjauan Kembali Keberadaan 'Kanal' di Kota

Majapahit”, Berkala Arkeologi No. 2 Tahun XXX November 2010. Yogyakarta:

Balai Arkeologi Yogyakarta. HIm. 13- 31/

Siagian, Renville, 2002. Candi - Sebagai warisan Seni dan Budaya Indonesia. Yogyakarta: Yayasan Cempaka Kencana.

Susantini, Rizky. 2007. "Mengenang Majapahit", Desawarnana-Buletin Arkeologi No. 2. Mojokerto: BP3 Propinsi Jawa Timur. HIm. 6-13.

Tim Penelitian, 2012. "Penelitian Arkeologi Di Situs Semarum Desa Semarum, Kecamatan Durenan, Kabupaten Trenggalek Jawa Timur", Laporan

Penelitian Arkeologi. Yogyakarta: Balai Arkeologi Yogyakarta

, 2013. "Bentuk dan Karakter Situs Semarum dan Situs Kamulan di Kecamatan Durenan, Kabupaten Trenggalek Jawa Timur (Tahap II)", Laporan Penelitian Arkeologi.Yogyakarta: Balai Arkeologi Yogyakarta

2014. "Bentuk dan Karakter Situs Semarum dan Situs

Kamulan di Kecamatan Durenan, Kabupaten Trenggalek Jawa Timur (Tahap

III)", Laporan Penelitian Arkeologi.Yogyakarta: Balai Arkeologi Yogyakarta

Utomo, Danang Wahyu. 2012. Laporan Peninjauan Struktur Bata Kuna Di Desa

Semarum, Kecamatan Durenan, Kabupaten Trenggalek. Trowulan: BP3

Propinsi Jawa Timur.

Wibowo, A.S., 1977. "Fungsi Kolam-Kolam Buatan di Ibukota Majapahit", Majalah Arkeologi Th. I No. 2 November 1997. Jakarta: FS UI. HIm. 36-45. 